\title{
MEMAHAMI STRUKTUR DATA DAN PROGRAM PASCAL
}

Abriani Dewi Oktavia

195120003

Fakultas Komputer

Abrianidewioktavia.student@umitra.ac.id

\begin{abstract}
Struktur data mempunyai arti untuk mengorganisasikan data menyerupai implentasi (penerapan) menjadi lebih terstruktur .

Turbo pascal menurut Bahasa program yaitu :

Sekumpulan intruksi dan perintah tersusun rapih hingga memiliki urutan logika yang tepat untuk persoalan.

Program adalah suatu implentasi Bahasa pemprograman intruksi atau perintah yang disusun sehingga mempunyai urutan logika hingga menyelesaikan suatu persoalan .

Algoritma merupakan inti dari semua program yang berupa langkah sistematis dan dirancang untuk menyelesaikan suatu masalah spesifikasi dengan usaha seminimal mungkin , penyelesaian yang disusun secara sistematis dan logis merupakan kunci utama dari Algoritma .
\end{abstract}

- Karakter Algoritma

1. Input

2. Output

3. Definite (jelas)

4. Efektive

5. Terminate ( Berakhir ) 


\section{Struktur Program Pascal :}

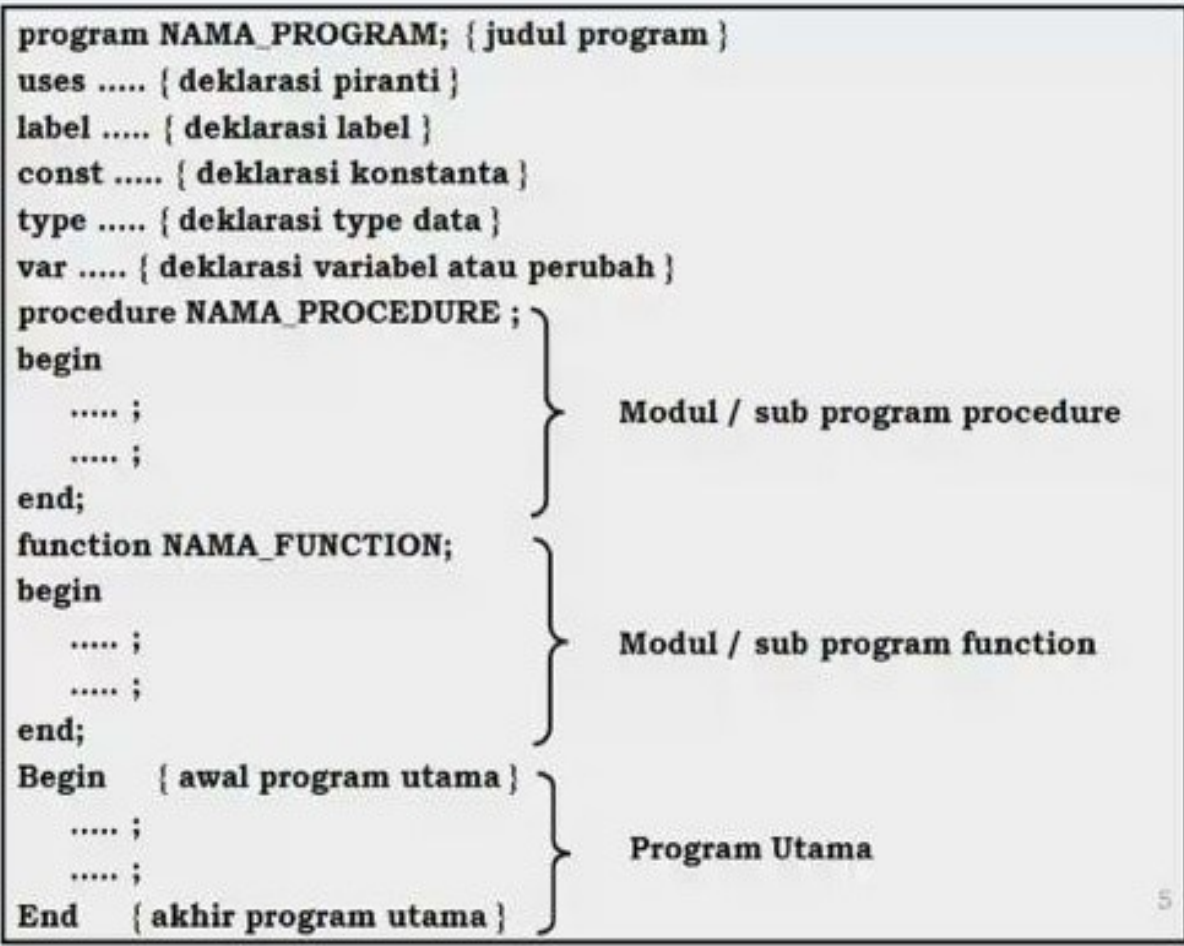

- Langkah - langkah Pembuatan Program

1. mendefinisikan permasalahan

2. membuat rumusan untuk memecahkan masalah kita dapat menyusunnya dalam bentuk pseudocode ataupun flowchart ex : pseudocode

Mulai

Input ( Bilangan 1)

Input ( Bilangan 2 )

Hasil $=$ Bilangan $1+$ Bilangan 2

Output ( Hasil ) 
Fakultas Komputer

Semester Genap II

Abriani Dewi Oktavia

Section 01

Selesai.

Ex : Flowchart

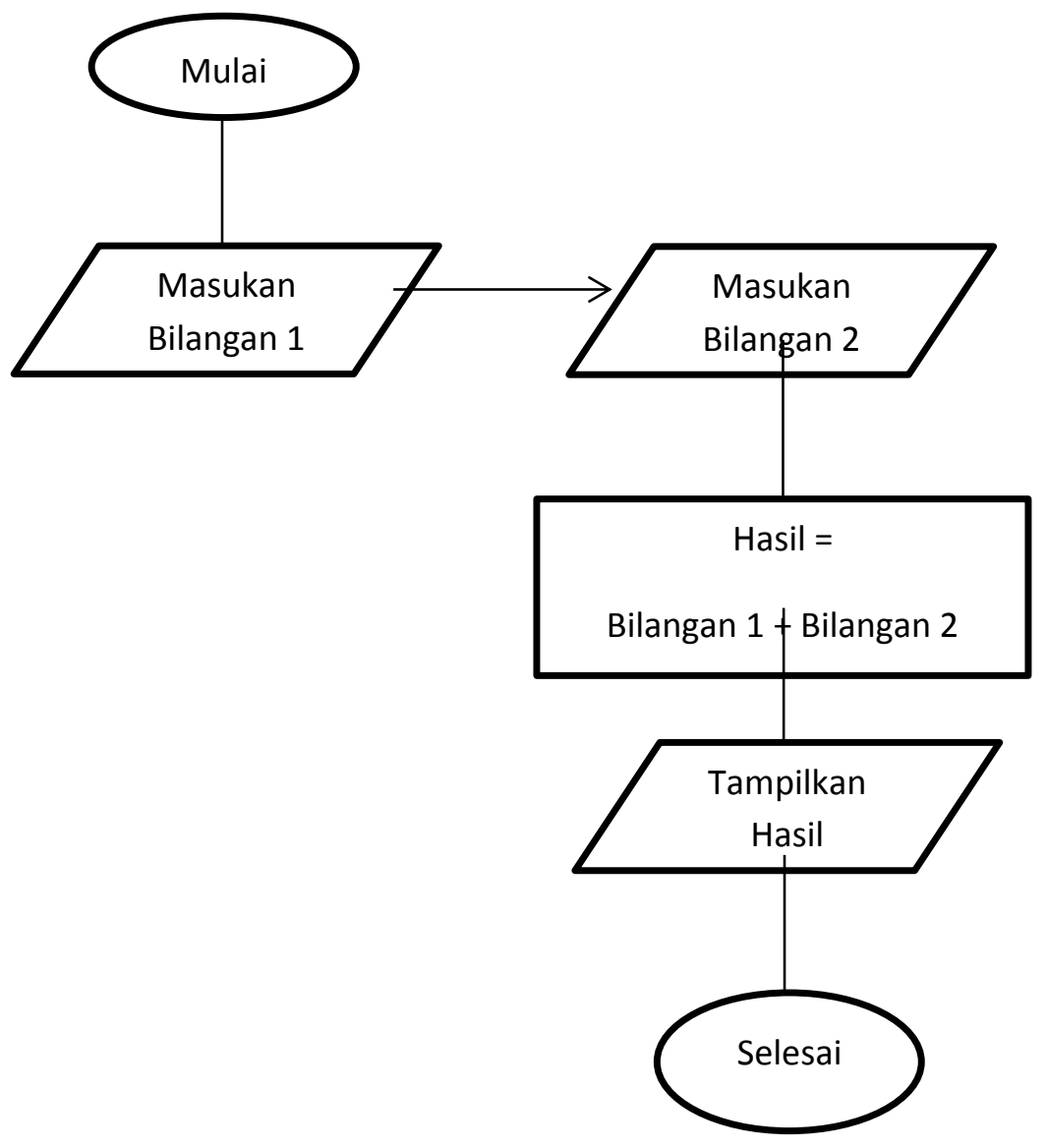




\section{A. PENDAHULUAN}

Membahas tentang Struktur Data mengenai Struktur Data Bahasa Program Turbo Pascal , Algoritma dan Struktur Data, Karakteristik Algoritma , Langkah - langkah pembuatan program dan Jenis - jenis Type Data

Struktur Data berarti tata letak data yang berisi kolom - kolom data , setiap baris dari kumpulan kolom - kolom tersebut dinamakan catatan ( record )

\section{- Jenis - jenis Type Data :}

1. Type Sederhana ( simple type)

a. type ordinal (untuk semua bilangan kecuali bilangan real)

@integer [-32768 ... 32767] 2 bytes

@shortint [-128 .. 127] 1 bytes

@)longint [-2147483648 .. 2147483647] 4 bytes

(a)boolean [benar .. salah] 1 bytes

@ char [u karakter 1 huruf ] 'A' 1 byte ( ASCII )

(a)byte [ 0 .. 255 ] 1 byte

b. type real (untuk bilangan Desimal) 6 bytes

2. Type string ( data yang berisi sederetan karakter)

'INFORMASI'

3. Type terstruktur (structured type) untuk ukuran tempat

a. Larik (Array ) memiliki hasil data dalam jumlah tetap namun dengan type sama, contoh : [ $1 . .100]$

b. Rekaman ( record ) serupa dengan array, tapi rekaman tidak harus serupa dengan type data yang sama

c. Himpunan ( set ) kumpulan objek yang mempunyai type data yang sama

d. Berkas ( file ) sejumlah kumpulan komponen yang bertipe data yang sama.

4. Type pointer ( dijelaskan dalam bab SENARAI BERANTAI)

\section{Contoh Type ARRAY:}

VAR nilai : ARRAY [1.. maks_mhs] of char

\section{Contoh Type RECORD :}

TYPE rec_mhs = record 


\section{Section 01}

Nim : string (10);

Nama : string (20);

Jur : string (15)

End ;

\section{B. PEMBAHASAN / KASUS STUDI}

Struktur Data yang mengorganisasikan data serupa dengan implentasi menjadi lebih terstruktur. Turbo Pascal yaitu sekumpulan intruksi atau perintah disusun rapih sehingga mempunyai urutan logika tepat untuk sebuah persoalan. Program yang menurut Bahasa intruksi atau perintah yang tersusun hingga memiliki logika sehingga dapat menyelesaikan suatu persoalan. Algoritma sebuah langkah sistematis yang dirancang untuk menyelesaikan suatu masalah dengan usaha seminimal mungkin. Karakteristik Algoritma ; Input ,Output , Definite ( jelas), Efektive, Terminate ( Berakhir )

\section{ID SECURITY QWTD4452377-ASP-5244166}

\section{KESIMPULAN}

Struktur Data memiliki fungsi untuk mengorganisasikan data sehingga penerapan atau pemeliharaan logika program menjadi lebih terstruktur, pembaca juga dapat mengetahui pengertian serta Langkah - langkah pembuatan program dan juga mengetahui beberapa Type Data Pemakaian struktur data yang tepat didalam proses pemograman, akan menghasilkan Algoritma yang jelas dan tepat sehingga menjadikan program secara keseluruhan lebih sederhana.Array merupakan bagian dari struktur data yaitu termasuk kedalam struktur data sederhana yang dapat didefinisikan sebagai pemesanan alokasi memory sementara pada computer.

\section{E. DISKUSI}

Saya bersama teman saya yang bernama MEGA AGUSTIN mendiskusikan tentang contoh ini dengan sangat baik hasil diskusi dari materi ini adalah kami dapat lebih memahami struktur data dan program pascal . 


\section{F. REFERENCE}

[1] O. M. Febriani and A. S. Putra, "Sistem Informasi Monitoring Inventori Barang Pada Balai Riset Standardisasi Industri Bandar Lampung," J. Inform., vol. 13, no. 1, pp. 90-98, 2014.

[2] A. S. Putra, "Paperplain: Execution Fundamental Create Application With Borland Delphi 7.0 University Of Mitra Indonesia," 2018.

[3] A. S. Putra, "2018 Artikel Struktur Data, Audit Dan Jaringan Komputer," 2018.

[4] A. S. Putra, "ALIAS MANAGER USED IN DATABASE DESKTOP STUDI CASE DB DEMOS."

[5] A. S. Putra, "COMPREHENSIVE SET OF PROFESSIONAL FOR DISTRIBUTE COMPUTING."

[6] A. S. Putra, "DATA ORIENTED RECOGNITION IN BORLAND DELPHI 7.0."

[7] A. S. Putra, "EMBARCADERO DELPHI XE 2 IN GPU-POWERED FIREMONKEY APPLICATION."

[8] A. S. Putra, "HAK ATAS KEKAYAAN INTELEKTUAL DALAM DUNIA TEKNOLOGY BERBASIS REVOLUSI INDUSTRI 4.0.”

[9] A. S. Putra, "IMPLEMENTASI PERATURAN PERUNDANGAN UU. NO 31 TAHUN 2000 TENTANG DESAIN INDUSTRI BERBASIS INFORMATION TECHNOLOGY."

[10] A. S. Putra, "IMPLEMENTATION OF PARADOX DBASE."

[11] A. S. Putra, "IMPLEMENTATION OF TRADE SECRET CASE STUDY SAMSUNG MOBILE PHONE."

[12] A. S. Putra, "IMPLEMENTATION PATENT FOR APPLICATION WEB BASED CASE STUDI WWW. PUBLIKLAMPUNG. COM.”

[13] A. S. Putra, "IMPLEMENTATION SYSTEM FIRST TO INVENT IN 
DIGITALLY INDUSTRY."

[14] A. S. Putra, "MANUAL REPORT \& INTEGRATED DEVELOPMENT ENVIRONMENT BORLAND DELPHI 7.0.”

[15] A. S. Putra, "PATENT AS RELEVAN SUPPORT RESEARCH."

[16] A. S. Putra, "PATENT FOR RESEARCH STUDY CASE OF APPLE. Inc."

[17] A. S. Putra, "PATENT PROTECTION FOR APPLICATION INVENT."

[18] A. S. Putra, "QUICK REPORT IN PROPERTY PROGRAMMING."

[19] A. S. Putra, "REVIEW CIRCUIT LAYOUT COMPONENT REQUIREMENT ON ASUS NOTEBOOK."

[20] A. S. Putra, "REVIEW TRADEMARK PATENT FOR INDUSTRIAL TECHNOLOGY BASED 4.0."

[21] A. S. Putra, "TOOLBAR COMPONENT PALLETTE IN OBJECT ORIENTED PROGRAMMING."

[22] A. S. Putra, "WORKING DIRECTORY SET FOR PARADOX 7."

[23] A. S. Putra, "ZQUERY CONNECTION IMPLEMENTED PROGRAMMING STUDI CASE PT. BANK BCA Tbk."

[24] A. S. Putra, D. R. Aryanti, and I. Hartati, "Metode SAW (Simple Additive Weighting) sebagai Sistem Pendukung Keputusan Guru Berprestasi (Studi Kasus: SMK Global Surya)," in Prosiding Seminar Nasional Darmajaya, 2018, vol. 1, no. 1, pp. 85-97.

[25] A. S. Putra and O. M. Febriani, "Knowledge Management Online Application in PDAM Lampung Province," in Prosiding International conference on Information Technology and Business (ICITB), 2018, pp. 181187.

[26] A. S. Putra, O. M. Febriani, and B. Bachry, "Implementasi Genetic Fuzzy System Untuk Mengidentifikasi Hasil Curian Kendaraan Bermotor Di Polda Lampung," SIMADA (Jurnal Sist. Inf. dan Manaj. Basis Data), vol. 1, no. 1, 
pp. 21-30, 2018.

[27] A. S. Putra, H. Sukri, and K. Zuhri, "Sistem Monitoring Realtime Jaringan Irigasi Desa (JIDES) Dengan Konsep Jaringan Sensor Nirkabel," IJEIS (Indonesian J. Electron. Instrum. Syst., vol. 8, no. 2, pp. 221-232.

[28] D. P. Sari, O. M. Febriani, and A. S. Putra, "Perancangan Sistem Informasi SDM Berprestasi pada SD Global Surya," in Prosiding Seminar Nasional Darmajaya, 2018, vol. 1, no. 1, pp. 289-294. 